\title{
Kamienne bruki Starego Rynku w Poznaniu jako element dziedzictwa kulturowego
}

\author{
Janusz Skoczylas ${ }^{1}$, Lukasz Skoczylas ${ }^{1}$
}
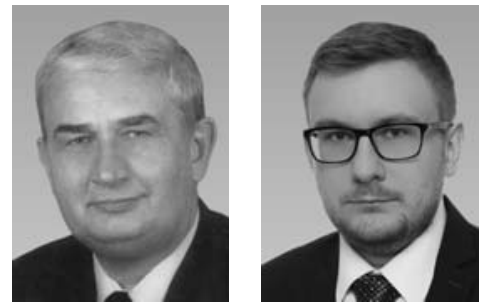

J. Skoczylas

Ł. Skoczylas

Stone pavements of the Old Market Square in Poznań as the element of the cultural legacy. Prz. Geol., 68: 535-539; doi: 10.7306/2020.20

A b s $t r a c t$. The article describes stone pavements forming the surface of the Old Market Square in Poznan. In the context of postulates of replacement of a historical stone surface with modern paving, the authors took the position that the quality as well as the amount of existing rock material is fully sufficient to carry out its renovation. First and foremost, it should concern the existing granite-gneiss, and more rarely basalt, quartz and porphyry paving stones, as well as granite paving slabs and granite curb stones.

Keywords: cobblestone, paving stone, flagstone, curb stone, stone road and pavement surfaces

Istotnym elementem analizy kamiennych bruków jest ich wartość dla dziedzictwa kulturowego. Poprzez refleksję nad tym, z jakiego materiału skalnego wykonano bruk oraz jak on wygląda, można definiować dawne kanały transportu, stan handlu i relacji międzynarodowych, a także stan rozwoju ekonomicznego danego miasta. Ważny jest także fakt, że w miastach, w których pokrywa brukowa przez lata była zmieniana tylko w ramach niewielkich remontów i uzupełnień ubytków, stan bruków pozwala wnioskować o wszystkich procesach naprawczych i ich ewolucji w różnych epokach historycznych. Razem sprawia to, że kamienne bruki mogą być ciekawym źródłem badań naukowych i przede wszystkim elementem zwiększającym turystyczną atrakcyjność przestrzeni miejskiej. W tym kontekście za zasadne uznajemy określenie bruków mianem dziedzictwa kulturowego, które rozumiemy jako wytwór człowieka o szczególnej wartości historycznej (Galusek, Jagodzińska, 2014).

Celem pracy była analiza petrograficzna kamiennych bruków Starego Rynku w Poznaniu oraz próba wskazania możliwości ich rewaloryzacji. W niniejszym artykule opisano historyczne uwarunkowania kładzenia kamiennej pokrywy rynku i jej stan obecny oraz określono możliwe sposoby przywrócenia jej dawnych właściwości użytkowych przy zachowaniu wartości kulturowej.

\section{DZIEJE KAMIENNYCH BRUKÓW W POZNANIU}

Od wieków utwardzanie ulic wytyczonych w przestrzeni miejskiej było prowadzone nie tylko w celu zapewnienia wygody i usprawnienia przemieszczania się osób i towarów, ale służyło również poprawieniu sanitarnego stanu miasta i higieny jego mieszkańców. Poznańskie ulice zaczęto utwardzać już we wczesnym średniowieczu, a proces ten trwa do dziś.

Wyniki prac archeologicznych prowadzonych w starej, lewobrzeżnej części miasta dowodzą, że w połowie XIII w. wiele ulic wyjazdowych i wokół rynku otrzymało kamienną nawierzchnię, często w postaci przypadkowych, a na pewno niewymiarowych głazów narzutowych, czyli - stosując termin XIX-wieczny - kamieni polnych (Kaniecki, 2004). Jednak zapiski o wydatkach miejskich mających postać cotygodniowych gratyfikacji dla brukarzy zaczęły się pojawiać dopiero od XVI w. Wcześniej do zbierania kamieni przeznaczonych do brukowania miejskich ulic wykorzystywano mieszkańców okolicznych wsi należących do miasta, tzw. wsi miejskich.

W średniowieczu głazami narzutowymi brukowano nie tylko ulice, ale również powierzchnie podwórzy, które mogły wówczas pełnić funkcję magazynów lub stanowić podłoże innych pomieszczeń, np. gospodarczych. W efekcie badań archeologicznych przy kamienicy nr 99 na Starym Rynku w Poznaniu wydzielono 4 poziomy bruku kamiennego (Kaniecki, 2004). Bruki z XVI i XVII w. często były naprawiane, szczególnie po powodziach i awariach nielicznej sieci wodociągowej, a także po remontach studni. Znane są ponadto opisy zabiegów renowacyjnych i napraw bruków zarządzanych z okazji przyjazdu do Poznania ważnych gości. Analizując stan poznańskich bruków, od 1754 r. można zauważyć większą niż poprzednio dbałość o stan nawierzchni dróg, popartą m.in. działalnością Komisji Dobrego Porządku, kiedy to miasto na reperację dróg przeznaczało rocznie ok. 100 tys. zł (Kaniecki, 2004).

Jeszcze w XVIII w. surowiec skalny potrzebny do brukowania ulic pozyskiwano tradycyjnie, tj. przez obciążenie okolicznych wieśniaków wjeżdżających do miasta obowiązkiem dostarczenia do rogatek co najmniej jednego kamienia nadającego się do brukowania. Z kolei ordynacja dla mieszkańców wsi Rataje z 1788 r. nakładała na nich obowiązek dostarczania corocznie 2 wozów kamieni od gospodarstw o powierzchni ok. 30 mórg, czyli tzw. jednej huby (Kaniecki, 2004). W 1816 r. reaktywowano dawny przepis o obowiązku dostarczenia przez osoby przywożące żywność na targ trzech kamieni polnych. Z kolei w $1846 \mathrm{r}$. wprowadzono podatek od psów i część uzyskiwanych z niego funduszy przeznaczano na utwardzenie nawierzchni ulic w Poznaniu. Dodać jeszcze można, że od każdej osoby przejeżdżającej przez poznańską dzielnicę Chwaliszewo pobierano tzw. brukowe (Trzeciakowscy, 1987).

\footnotetext{
${ }^{1}$ Wydział Nauk Geograficznych i Geologicznych, Uniwersytet im. Adama Mickiewicza w Poznaniu, ul. Bogumiła Krygowskiego 12,60-680 Poznań; skocz@amu.edu.pl

${ }^{2}$ Wydział Socjologii, Uniwersytet im. Adama Mickiewicza w Poznaniu, ul. Augustyna Szamarzewskiego 89, 60-568 Poznań; luke@amu.edu.pl
} 
Interesujące są uwagi Skuratowicza (1991) na temat bruków Poznania z lat 1890-1918. Uważa on, że do 1918 r. niemal wszystkie ulice tego miasta udało się pokryć brukami z krystalicznych skał importowanych z Gotlandii, w tym również Stary Rynek, plac Wilhelmowski (pl. Wolności) i plac Królewski (pl. C. Ratajskiego). Także szeroko wytyczone wówczas chodniki pokryto wielkimi płytami granitu (ograniczonymi granitowymi krawężnikami), które - jak pisze Skuratowicz (1991) - zostały sprowadzone z Gotlandii lub Śląska. Rozpatrując stan ówczesnych dróg na nieco szerszym tle geograficznym warto przypomnieć, że w $1816 \mathrm{r}$. w całym Królestwie Pruskim było jedynie 55,6 km szos. Jednak już w 1817 r. rozpoczęto prace nad ogólnokrajowym, rozszerzonym planem ich budowy. Natomiast pierwsze drogi wylotowe z Poznania powstawały równocześnie z rozbudową fortyfikacji wokół miasta (Dohnalowa, 1975, 1994). Dodać jeszcze można, że w 1843 r. utworzono w Poznaniu Prowincjonalny Fundusz Budowy Dróg, który funkcjonował do 1867 r. Początkowo brukowanie ulic postępowało wolno i w sposób prymitywny, mało profesjonalny. Do budowy nawierzchni używano głazów narzutowych nazywanych kocimi łbami lub głowaczami. Od 1851 r. coraz większą uwagę przywiązywano do wytyczania chodników i rynsztoków. Obowiązek brukowania ulic i układania chodników spoczywał na właścicielach posesji, podczas gdy władze miasta pokrywały połowę kosztów tych prac. W latach 1867-1868 długość kamiennych chodników w Poznaniu wynosiła aż 22400 m. Podkreślano, że: $w$ monarchii pruskiej żadne inne miasto o zbliżonej liczbie ludności i podobnej odległości od kamieniołomów nie posiada równie rozbudowanej sieci chodników, co Poznań (Dohnalowa, 1994). W latach 1900-1914 ułożono w Poznaniu $492350 \mathrm{~m}^{2}$ nowych nawierzchni bruku.

Dokładniejsze dane o pracach nad odnowieniem i wymianą bruków w Poznaniu przedstawił Nowakowski (1929a, b). Według niego do 1890 r. ulice w Poznaniu brukowano prymitywnie $\mathrm{i}$ to przede wszystkim kamieniem polnym, czyli głazami narzutowymi. Ponadto stwierdził on, że od roku 1890 do 1899 wykonano ok. $91800 \mathrm{~m}^{2}$ nowych nawierzchni, kosztem 1620821 marek w złocie. Nowe nawierzchnie otrzymały m.in. obecne ul. Świętego Marcina, ul. 27 grudnia, plac Wolności, Aleje Marcinkowskiego, ul. 3 Maja, ul. Rzeczypospolitej, ul. Podgórna i ul. Nowa. Dodać wypada, że w 1893 r. na ul. św. Marcina, po raz pierwszy w Poznaniu, zastosowano nawierzchnię asfaltową (Nowakowski, 1929a). Od roku 1900 do 1914 wykonano w mieście ok. $482350 \mathrm{~m}^{2}$ nowych nawierzchni kosztem $8 \mathrm{mln}$ marek w złocie, dostarczonych przez fundusze miejskie, państwowe i prywatne. Z kolei od roku 1915 do 1918 ułożono jedynie ok. $18000 \mathrm{~m}^{2}$ nawierzchni ulic, a w latach 1919-1921 wykonano tylko naprawy kosztem 20000 franków szwajcarskich (Nowakowski, 1929a, b).

W 1922 r. drobną kostką krajową wybrukowano ul. Ratajczaka, między ul. św. Marcina a ul. Ogrodową. Przy okazji usunięto asfalt. Według M. Nowakowskiego kamień był sprowadzany głównie z zagranicy, w kraju nie było bowiem odpowiednich mocy przerobowych do wykorzystania surowca skalnego z Wołynia i Tatr.

W 1923 r. przy okazji przebudowy pl. Wolności na powierzchni $5134 \mathrm{~m}^{2}$ położono bruk granitowy w układzie rzędowym. W tym samym roku na ul. Szkolnej wymieniono asfalt i bruk drewniany, zastępując go na powierzchni 401,5 $\mathrm{m}^{2}$ brukiem w układzie rzędowym; również na ulicy Młyńskiej położono $984 \mathrm{~m}^{2}$ bruku. Do ciekawostek można zaliczyć fakt odkopania pod ul. Głogowską - na odcinku
$80 \mathrm{~m}$ - bruku z granitu (o powierzchni ok. $1160 \mathrm{~m}^{2}$ ) zasypanego podczas przygotowań do wschodnio-pruskiej wystawy krajowej w 1911 r. Uzyskane bruki wykorzystano do budowy i napraw innych obiektów w Poznaniu (Nowakowski, 1929a). Dodać jeszcze warto, że wiele prac brukarskich wykonywano w związku z kładzeniem drugiego toru tramwajowego, np. od mostu Chwaliszewskiego do dojazdu na most Bolesława Chrobrego.

W 1926 r. kostką granitową wybrukowano w Poznaniu powierzchnię $8820 \mathrm{~m}^{2}$. Ponadto głazami narzutowymi wybrukowano $30167 \mathrm{~m}^{2}$, a także dokonano $30767 \mathrm{~m}^{2}$ napraw ulicznych. Z kolei w 1928 r. skupiono się przede wszystkim na poprawie jakości ulic otaczających miejsce Powszechnej Wystawy Krajowej (Nowakowski, 1929a; Nestorowicz, 1935). W okresie międzywojennym, podobnie jak w przeszłości, intensyfikacja prac brukarskich następowała wraz z nadchodzącymi ważnymi wydarzeniami, najczęściej wystawienniczymi, jak np. Powszechna Wystawa Krajowa w 1928 r. czy Międzynarodowa Wystawa Komunikacji i Turystyki połączona z XXII Międzynarodowym Kongresem Komunikacyjnym w 1930 r. Interesująca jest też informacja, że w 1930 r. - aby nie wstrzymywać na dłuższy czas drożności jednego z najważniejszych traktów komunikacyjnych centrum ówczesnego Poznania - ulicę Nową (obecnie. I. Paderewskiego) przebudowano w ciągu zaledwie 38 godzin nieprzerwanej pracy (Czarnecki, 1987).

W pierwszej dekadzie okresu międzywojennego władze miejskie odczuwały dotkliwy brak profesjonalnie obrobionych kamieni brukowych, głównie kostek granitowych. Wynikało to ze zmiany granic państwowych i przerwania ciągów transportowo-handlowych funkcjonujących przed I wojną światową. Ratowano się importami ze Szwecji i Czech, a także granitami krajowymi z Wołynia. Ponadto eksperymentowano $\mathrm{z}$ innymi skałami krajowego pochodzenia, takimi jak bazalty (okolice Janowej Doliny), porfiry krakowskie (Miękinia, Filipowice) oraz piaskowce kwarcytowe (Tatry). Mimo to Nowakowski (1929a) podkreślał, że: Na razie jesteśmy jednak zależni od dostaw granitów szlachetnie obrobionych z zagranicy.

Powojenne zmiany w przestrzeni Starego Miasta w Poznaniu spowodowały dalsze zwiększenie rozprzestrzenienia i różnorodności materiału skalnego użytego do wykonania kostki brukowej oraz skomplikowanie jej układów.

\section{ANALIZA KAMIENNEGO WYSTROJU NAWIERZCHNI STAREGO RYNKU}

Przeważająca część powierzchni Starego Rynku w Poznaniu została wybrukowana kostką rzędową o przeciętnych wymiarach $20 \times 16 \mathrm{~cm}$ i $20 \times 20 \mathrm{~cm}$. Należy podkreślić, że podstawowym i zasadniczym materiałem skalnym użytym do wybrukowania rynku były krystaliczne skały magmowe i metamorficzne. Są to różnoziarniste granity, najczęściej gruboziarniste lub - szerzej ujmując klasyfikację skał magmowych - granitoidy. Stanowią one materiał skalny od 50 do $60 \%$ wszystkich rozpoznanych bruków. Jednak wskutek licznych napraw i przebudów nawierzchnia rynku sprawia dzisiaj wrażenie, że jest wybrukowana niesegregowaną kolorystycznie kostką o rozmiarach większych niż współcześnie stosowane. Obok granitoidów do brukowania rynku powszechnie stosowano również skały metamorficzne, głównie różnego rodzaju gnejsy. Cechuje je podobna do większości granitów 


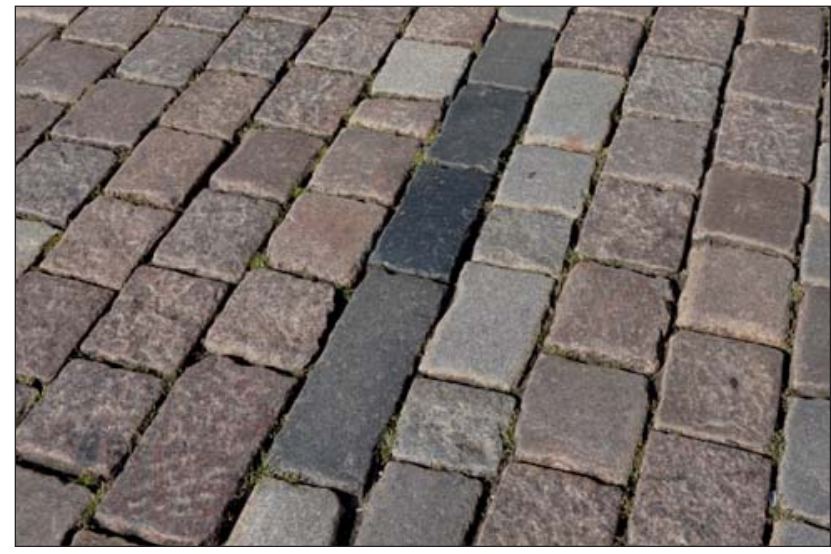

Ryc. 1. Stary Rynek w Poznaniu - linijne (rzędowe) ułożenie kostek bazaltowych wśród bruku granitowo-gnejsowego. Wszystkie fot. J. Skoczylas

Fig. 1. Old Market Square in Poznań - linear (row) arrangement of basalt cubes among granite-gneiss pavements. All photos by J. Skoczylas

ciemnoczerwonawa barwa. Ich frekwencję można ocenić na 30-35\%. Niezależnie od tego dominującego materiału skalnego zauważono także obecność czarnych bazaltów, kwarcytów, a nawet porfirów. Kostki bazaltowe stanowią raczej doraźne uzupełnienia pojedynczych elementów lub tworzą linijnie ułożone ciagi prowadzące do studzienek kanałowych. Niekiedy znowu przedzielają duże powierzchnie granitowych bruków (ryc. 1). Można również zauważyć pojedyncze kostki wykonane z kwarcytów. W środkowej części rynku, na północ od budynku ratusza występuje 7 rzędów kostki kwarcytowej. Z kolei w okolicy pierzei południowo-zachodniej można zauważyć pojedyncze kostki brukowe wykonane z porfirów.

Na poznańskim rynku przeważa rzędowe ułożenie bruków. Jednak w jego północno-zachodniej części, obok kamienicy nr 85, stwierdzono ukośne ułożenie kostek bruku w stosunku do krawędzi rynku, określane w budownictwie jako jaskółczy ogon (ryc. 2). Bruk ułożony w ten sposób został wykonany z bardziej jednolitego surowca skalnego - granitowo-gnejsowego o ciemnoczerwonym zabarwieniu. Podobny materiał skalny, być może wtórnie, wykorzystano do wybrukowania powierzchni przed budynkiem Wagi, od północnej strony rynku. W bruku pod zachodnią pierzeją rynku, a także południową, szczególnie u wylotu ulicy Wrocławskiej, dominuje ciemnoczerwonawy, granitowo-gnejsowy surowiec skalny (ryc. 3). Natomiast pod wschodnią pierzeją przeważa szara kostka granitowa. Najbardziej zniszczony jest bruk w południowo-zachodniej części rynku (ryc. 4), w której jest widoczne największe wtórne (?), petrograficzne zróżnicowanie nawierzchni. W części tej występują ciemnoczerwone granity i sjenity, a także ciemnoczerwone gnejsy, szare różnoziarniste granity, szare kwarcyty, czerwone porfiry i czarne bazalty. Gdzieniegdzie są widoczne także nieliczne ubytki całej kostki lub jej fragmentów.

Płaszczyzny chodnikowe są pokryte dużymi płytami, najczęściej z szarego granitu, o zmiennych wymiarach, przeważnie $125 \times 78 \mathrm{~cm}$ lub $113 \times 133 \mathrm{~cm}$. Od powierzchni rynku chodniki są oddzielone krawężnikami wykonanymi w ok. 98\% z szarego granitu. Po bokach płyt chodnikowych ułożono drobną kostkę bazaltową, miejscami była ona uzupełniana kostką granitową podobnych rozmiarów (ryc. 5-6).

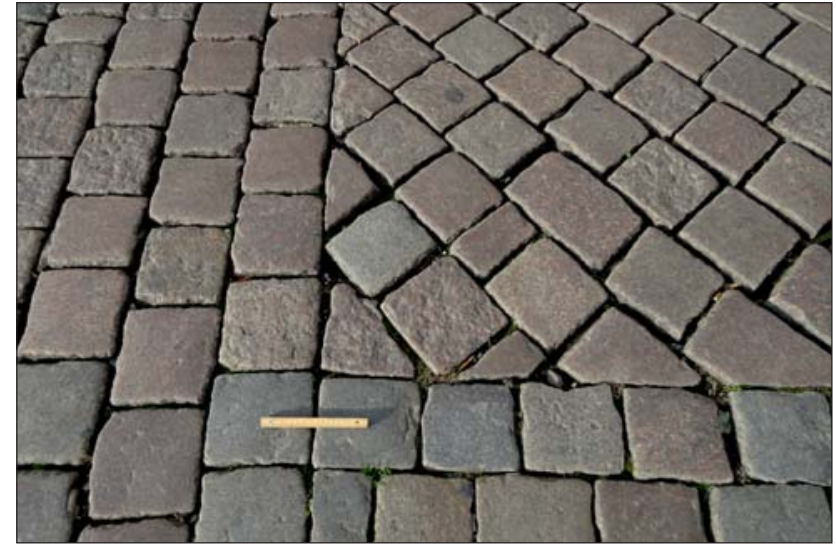

Ryc. 2. Północno-zachodni narożnik Starego Rynku w Poznaniu - połączenie rzędowego ułożenia kostek brukowych z ułożeniem w jaskółczy ogon

Fig. 2. North-west corner of Old Market Square in Poznań - a combination of a row arrangement of paving stones with a dovetail arrangement

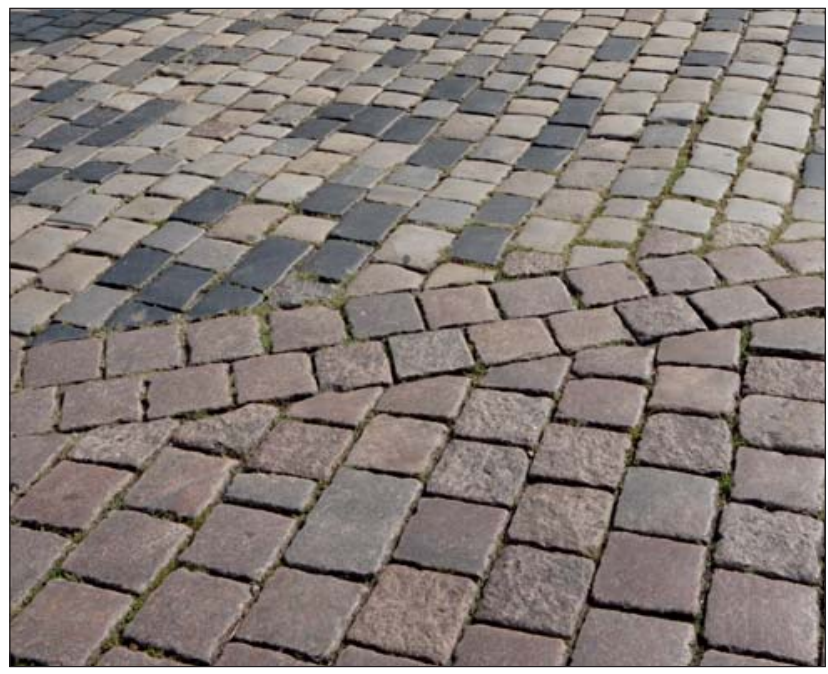

Ryc. 3. Ciemnoczerwone kostki granitowo-gnejsowe, szare kostki granitowe oraz czarne kostki bazaltowe jako uzupełnienie zachodnia strona Starego Rynku w Poznaniu przed Odwachem (dawną siedzibą straży miejskiej)

Fig. 3. Dark red granite-gneiss cubes, gray granite cubes and black basalt cubes as a supplement - the western fragment of the Old Market Square in Poznań before Guardhouse

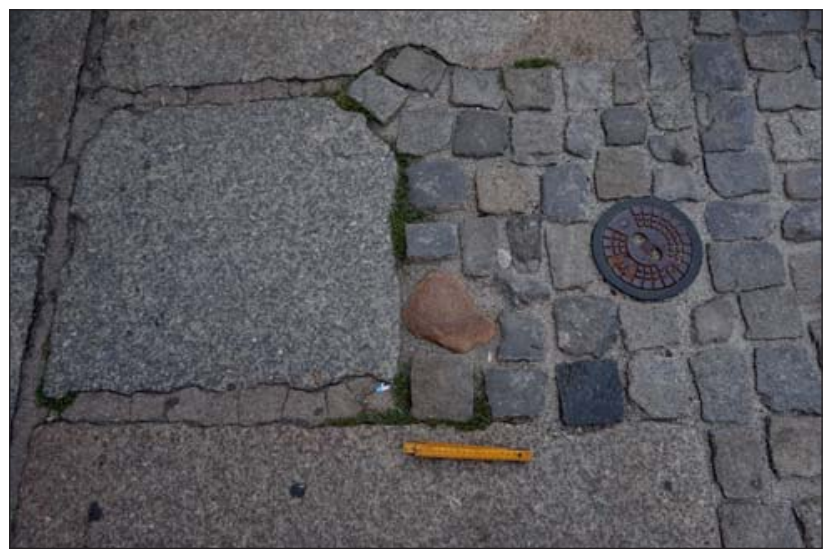

Ryc. 4. Przykład uzupełnień brukarskich zniszczonej płyty chodnikowej na Starym Rynku w Poznaniu

Fig. 4. An example of paving additions to a damaged pavement slab on Old Market Square in Poznań 


\section{PROBLEMY ZACHOWANIA KAMIENNEGO DZIEDZICTWA}

Surowiec skalny, z którego wykonano duże kostki brukowe barwy ciemnoczerwonej, pochodzi ze Skandynawii. Mało prawdopodobne jest, że kostki te wykonano ze zbieranych w okolicy głazów narzutowych, przytransportowanych ze Skandynawii przez lądolód. Bardziej wiarygodne wydaje się przypuszczenie, że zostały one sprowadzone ze Szwecji w postaci gotowego produktu. Przyczynił się do tego m.in. rozwój linii kolejowych, który w drugiej połowie XIX w. spowodował, że do Prus zaczęto masowo sprowadzać szwedzkie granity i inne skały krystaliczne, takie jak sjenity, gnejsy, dioryty, gabra i diabazy (Król i in., 2004). Obecnie w kraju nie mamy ani potrzeby, ani możliwości produkcji takich bruków na większą skalę, a import kostki brukowej ze Szwecji byłby nieopłacalny i przez to mało prawdopodobny. Zagadnienia te wymagaja jednak historyczno-gospodarczo-handlowej weryfikacji. Jeśli pogląd autorów w tej kwestii jest trafny, należy przyjąć, że materiał skalny barwy ciemnoczerwonej, potrzebny do renowacji nawierzchni rynku w Poznaniu i przylegających do niego ulic, trzeba pozyskiwać poprzez wtórne wykorzystanie starej kostki brukowej. Koniecznie należy ją na nowo ułożyć, zgodnie $\mathrm{z}$ najlepszymi zasadami i ten-

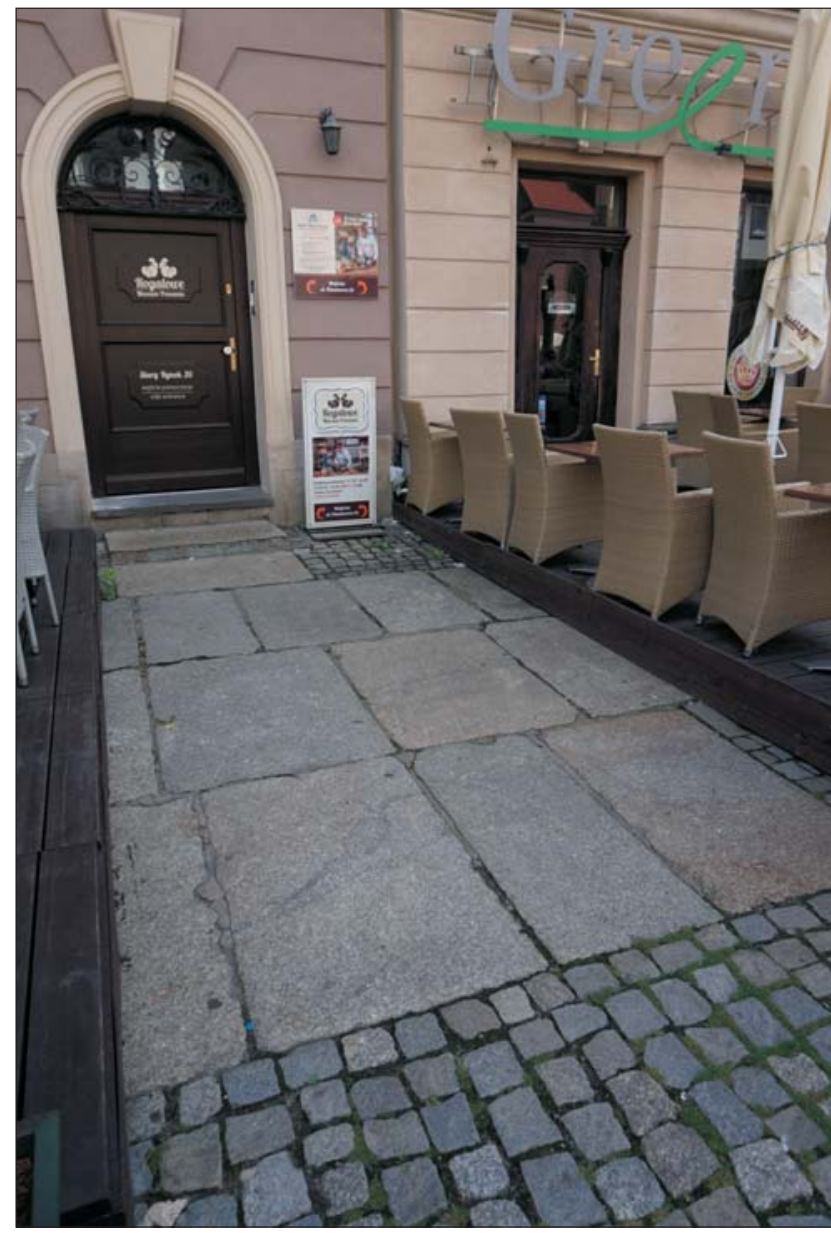

Ryc. 5. Granitowe płyty chodnikowe - otoczone drobną kostką granitową - ułożone pod wschodnią pierzeją Starego Rynku w Poznaniu

Fig. 5. Granite flagstones - surrounded by small granite blocks arrangement near eastern frontage on Old Market Square in Poznań dencjami współczesnej sztuki brukarskiej, realizując starożytną triadę Witruwiusza o trwałości, użyteczności i pięknie każdej budowli.

Szara kostka granitowa, jeżeli zajdzie taka potrzeba, może być uzupełniona granitami dolnośląskimi (ze Strzegomia, Strzelina lub Strzeblowa). Również krawężniki, które są wykonane $\mathrm{z}$ granitu, najczęściej szarego, można uzupełniać wykorzystując materiał wtórny lub granity z kamieniołomów dolnośląskich. Także większość płyt chodnikowych, ułożonych na rynku, wykonano z szarych, przeważnie gruboziarnistych granitów, które jeszcze w połowie XIX w. sprowadzano do Poznania z obszaru dzisiejszego Dolnego Śląska (Karolczak, 2017). Dodać jednak wypada, że obecne płyty chodnikowe przypominaja raczej granity z Žulowej (dawniej Friedberg), występujące na czeskim Śląsku. Granit z Žulowej (a žula oznacza po czesku granit) pochodzi z południowego krańca wystapień granitów dolnośląskich, kończących się w Strzelinie (Sylwestrzak, Kachnic, 2010). Granity te zrobiły wielką karierę dzięki swej przydatności do celów inżynierskich. Wraz z rozbudową linii kolejowych stały się popularne na obszarze Austro-Węgier i Prus. Były one masowo stosowane do budowy fortyfikacji, krawężników i płyt chodnikowych. Eksportowano je nawet do Włoch, Holandii, Belgii, Anglii i USA (Sylwestrzak, Kachnic, 2010).

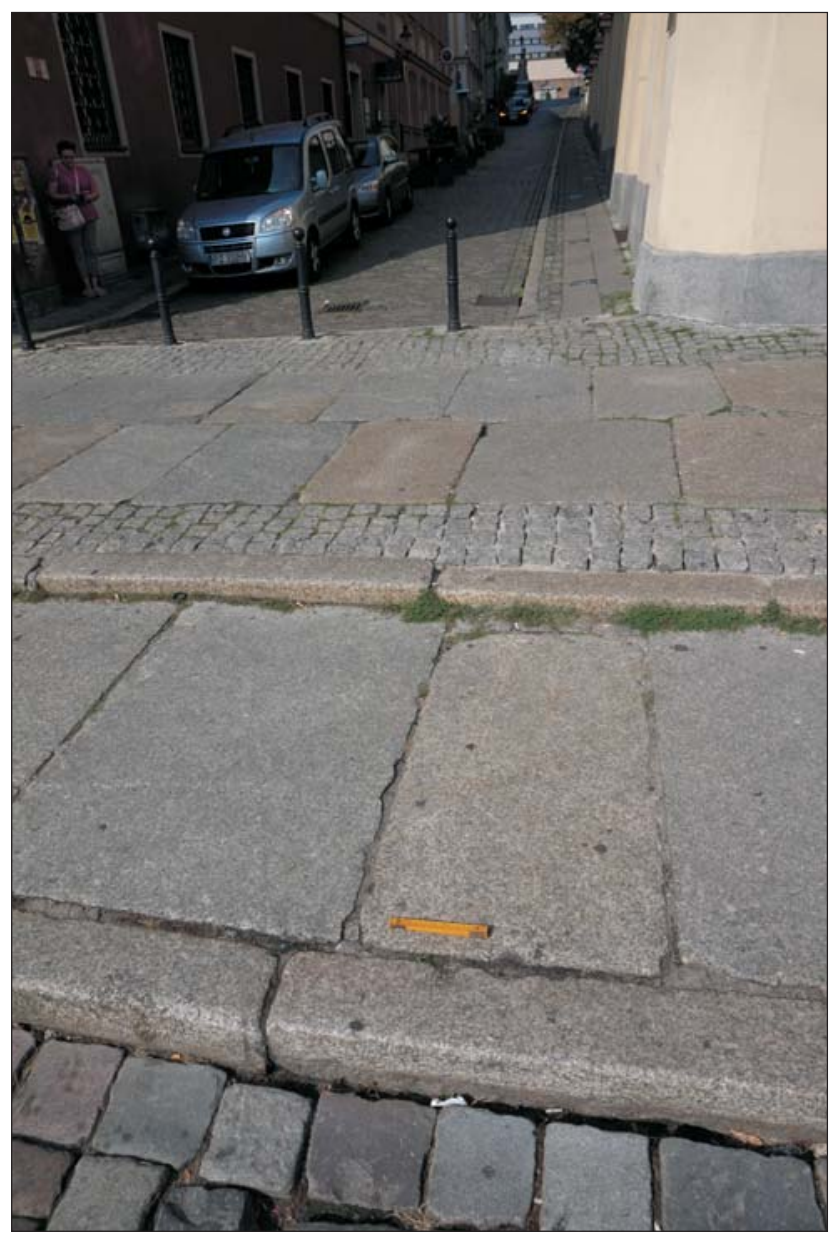

Ryc. 6. Granitowe płyty chodnikowe otoczone drobną kostką granitową i ograniczone krawężnikami z szarego granitu - zachodnia strona Starego Rynku w Poznaniu

Fig. 6. Granite flagstones surrounded by small granite blocks and limited by gray granite curbs - western frontage on Old Market Square in Poznań 
Z surowcowego punktu widzenia nie powinno być również problemu z uzupełnieniem kostek bazaltowych. $\mathrm{W}$ czasach zaboru pruskiego były one sprowadzane do Poznania głównie z Dolnego Śląska. W okresie międzywojennym korzystano ze złóż bazaltu na Wołyniu, m.in. z kamieniołomów w Janowej Dolinie i Berestowcu (Skalmowski, 1937; Nieć, 2002). Natomiast od zakończenia II wojny światowej eksploatuje się bazalty w Sudetach i na ich przedpolu, gdzie na powierzchni ziemi naliczono 314 wystapień tej skały. Zatem wydaje się, że produkcja drobnych kostek chodnikowych z bazaltu jest możliwa. Problem może stwarzać jedynie sposób ich obróbki. Należy też zadać ważne pytanie, czy kostki bazaltowe większych rozmiarów, wstawione $\mathrm{w}$ bruku pojedynczo lub ułożone linijnie, należy zachować, czy być może zastąpić innymi, ponieważ $\mathrm{w}$ wielu przypadkach pojedyncze czarne kostki bazaltowe stanowią wtórne uzupełnienia brakujących kostek granitu lub gnejsu.

Siedem rzędów płyt kwarcytowych, leżących w północnej części rynku, zostało wkomponowanych do nawierzchni brukowej prawdopodobnie w okresie międzywojennym, a dokładniej w pierwszej dekadzie tego okresu. Ze względu na gorsze parametry techniczne i użytkowe ich ewentualne braki nie powinny być uzupełniane. Kwarcyty te były eksploatowane w okolicach Zakopanego (prawdopodobnie w kamieniołomie nad Capkami) i w jego okolicach produkowano kostki brukowe (Kotański, 1971).

Stosunkowo rzadko i nie wprost pojawiają się także informacje o imporcie do Poznania bruku $\mathrm{z}$ granitu karkonoskiego, a w okresie międzywojennym wołyńskiego i tatrzańskiego (Nowakowski, 1929a). Ze względu jednak na fakt, że Tatry i Karkonosze są terenem parków narodowych, eksploatacja tych skał, w jakiekolwiek ilości, jest niemożliwa.

Tereny okolic Klesowa na Wołyniu są poza granicami naszego kraju i nie jest jasny status tamtejszych prac wydobywczych. Wydaje się jednak, że dostarczany stamtąd materiał skalny, w postaci drobniejszej granitowej kostki brukowej, nie jest zauważalny w okolicach Starego Rynku w Poznaniu. Stwierdzone pojedyncze fragmenty bruku z kostki porfirowej o większych rozmiarach nie mają istotnego znaczenia w ogólnym problemie rewaloryzacji nawierzchni rynku.

W obecnej sytuacji rewaloryzację nawierzchni Starego Rynku w Poznaniu mogą utrudniać nie tyle problemy związane z jakością oraz ilością materiału skalnego, co raczej wola i umiejętności profesjonalnego przeprowadzenia tego zabiegu. Generalizując, można stwierdzić, że rewaloryzacja bruków tego rynku w mniejszym stopniu powinna dotyczyć rodzaju użytego materiału skalnego, natomiast w zasadniczym stopniu - sztuki kamieniarskiej, sposobu posadowienia kostek brukowych i ich łączenia. Szczególne znaczenie ma to $\mathrm{w}$ przypadku pierwotnego ułożenia kostki brukowej z lat 1890-1899, które zachowało się w północno-zachodniej części rynku, gdzie mamy ułożenie ciemnoczerwonego, granitowo-gnejsowego bruku w tzw. jaskółczy ogon.

Współcześnie bruki Starego Rynku noszą ślady licznych etapów zmian i przebrukowań, uzupełnień i napraw, w związku z tym nie tworza jednolitej, trwałej historycznie przestrzeni z XIX w. lub przełomu wieków XIX i XX. Jednak właśnie to ich zróżnicowanie oddaje ciagłość zmian historyczno-technologicznych i w tym sensie stanowi o wyjątkowości substancji brukarskiej centrum Poznania. W przeciwieństwie do wielu miast (np. Wrocławia), które w czasie odbudowy ze zniszczeń wojennych, w trakcie remontów lub procesów rewaloryzacyjnych, wymieniły substancję brukową na dużych obszarach tkanki miejskiej, Poznań pozostaje w tym względzie miastem wyróżniającym się różnorodnością zastosowanych materiałów skalnych oraz ich historyczną adekwatnością wobec zmian urbanistycznych i technologicznych. Należy przy tym zwrócić uwagę, że sposób ułożenia kostek drogowych w centrum Poznania już od dawna ma znaczenie turystyczno-informacyjne. Na przykład fragmenty chodników i jezdni wykonane z czerwonej kostki betonowej, wyraźnie odróżniające się od okolicznych bruków, wskazują na miejsca, w których w średniowiecznym i nowożytnym Poznaniu znajdowały się nieistniejące już fragmenty murów miejskich oraz ważne elementy systemu umocnień (bramy i baszty). Obok nich znajdują się metalowe tabliczki wyjaśniające znaczenie charakterystycznego układu kostek. Tabliczki te, o wymiarach $70 \times 30 \mathrm{~cm}$, zamontowano z inicjatywy Zarządu Dróg Miejskich w 2013 r. jako element systemu identyfikacji miejskiej (Roik, 2013). Ten sposób upamiętniania dawnych obiektów architektonicznych i wykorzystywania fragmentów jezdni oraz chodników do celów turystyczno-edukacyjnych wydaje się spełniać swoją funkcję w sposób satysfakcjonujący. Podobną funkcję mogą pełnić oryginalne kostki brukowe formujące nawierzchnię Starego Rynku, wymagałoby to jednak umieszczenia w przestrzeni miejskiej odpowiednich oznaczeń oraz opracowania spójnej koncepcji ekspozycyjnej.

\section{LITERATURA}

CZARNECKI W. 1987 - To był też mój Poznań. Wyd. Poznańskie. DOHNALOWA T. 1975 - Rozwój transportu w Wielkopolsce. 1815-1914. PWN, Warszawa-Poznań.

DOHNALOWA T. 1994 - Handel, transport, komunikacja. [W:] Topolski J., Trzeciakowski J. (red.), Dzieje Poznania 1793-1918. PWN, Warszawa-Poznań, t. 2: 207-2012.

GALUSEK Ł., JOGODZIŃSKA K. 2014 - Dziedzictwo. [W:] Saryusz-Wolska M., Traba R. (red.), Modi memorandi. Leksykon kultury pamięci. Wyd. Nauk. Scholar, Poznań: 106-111.

KANIECKI A. 2004 - Poznań. Dzieje miasta wodą pisane. Wyd. PTPN, Poznań.

KAROLCZAK W. 2017 - Antoni Krzyżanowski i jego fabryka. Kronika Miasta Poznania, 3: 217-232.

KOTAŃSKI Z. 1971 - Przewodnik geologiczny po Tatrach. Wyd. Geol., Państw. Inst. Geol.

KRÓL D., WOŽNIAK P.P., ZAKRZEWSKI L. 2004 - Kamienie szwedzkie w kulturze i sztuce Pomorza. Muz. Archeol. w Gdańsku.

NESTOROWICZ M.W. 1935 - Sprawa drogowa w Polsce. Wende i S-ka, Warszawa.

NIEĆ M. 2002 - Złoża kopalin budowlanych i drogowych. [W:] Ney R. (red.), Surowce skalne. Kamienie budowlane i drogowe. Wyd. IGSMIE PAN, Kraków: 9-140.

NOWAKOWSKI M. 1929a - Budowa i utrzymanie ulic, placów i dróg miejskich. [W:] Księga Pamiątkowa Miasta Poznania. Nakładem Magistratu Stołecznego Miasta Poznania: 547-563.

NOWAKOWSKI M. 1929b - Roboty oddziału drogowego. Niwelacja pofortyfikacyj i inne roboty doraźne. [W:] Księga Pamiątkowa Miasta Poznania. Nakładem Magistratu Stołecznego Miasta Poznania: 533-546. ROIK M. 2013 - Były mury miejskie, a dzisiaj są tablice. Głos Wielkopol., 197: 5 .

SKALMOWSKI W. 1937 - Naturalne materiały kamienne w budownictwie drogowym. Ze szczególnym uwzględnieniem materiałów krajowych. Drog. Inst. Bad. Pol. Warsz.

SYLWESTRZAK H., KACHNIC J. 2010 - Kamienne tworzywo sztuki. Wyd. Nauk. Uniw. Mikołaja Kopernika, Toruń.

SKURATOWICZ J. 1991 - Architektura Poznania 1890-1918. Wyd. Nauk. UAM, Poznań.

TRZECIAKOWSCY M. i L. 1987 - W dziewiętnastowiecznym Poznaniu. Wyd. Poznańskie.

Praca wpłynęła do redakcji 16.01.2020 r.

Akceptowano do druku 5.03.2020 r. 